\title{
WASIAT WAJIBAH UNTUK ANAK ANGKAT PERSPEKTIF SIYĀSAH AL-SYAR'IYYAH
}

\author{
Munadi Usman \\ Institut Agama Islam Negeri Lhokseumawe \\ Email: munadiusman83@gmail.com

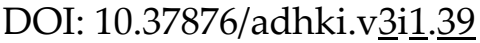

\begin{abstract}
Provisions of the wajibah testament to adopted child contained in the Compilation of Islamic Law Article 209 verse 1 and 2 constitute a renewal of Islamic inheritance law in Indonesia, but many legal experts doubt the validity of this provision and assume it does not have a clear legal basic in the form of nas (mașadir al-ahkām), the method of istinbath (qaidah al-ahkām) and the purpose or legal implications (maqașid al-ahkam). This study aims to verify the validity of the wajibah testament to adopted child with the siyassah al-shar'iyyah approach. The results of the study showed that the wajibah testament to the adopted child are legal rules that run based on government policy to resolve the issue of inheritance between heirs or persons who have a close relationship with the heir but is prevented from inheriting. The government is making the wajibah testament for adopted child in KHI as a solution to resolve this problem.
\end{abstract}

Keyword: Wajibah Testament, Adopted Child, Siyāsah al-Shar'iyyah

\begin{abstract}
Abstrak
Ketentuan wasiat wajibah kepada anak angkat yang termuat dalam Kompilasi Hukum Islam Pasal 209 ayat 1 dan 2 merupakan wujud pembaruan hukum kewarisan Islam di Indonesia, namun banyak ahli hukum yang meragukan keabsahan ketentuan ini dan menganggap tidak memiliki landasan hukum yang jelas berupa naș (mașadir al-ahkām), metode istinbath (qaidah al-ahkām) dan tujuan atau implikasi hukum (maqașid al-ahkam). Penelitian ini bertujuan untuk menguji keabsahan ketentuan wasiat wajibah untuk anak angkat melalui pendekatan siyāsah al-syar'iyyah. Hasil penelitian menunjukkan bahwa wasiat wajibah kepada anak angkat merupakan aturan hukum yang berjalan berdasarkan kebijakan pemerintah untuk menjawab persoalan di antara ahli waris atau orang yang memiliki hubungan dekat dengan pewaris namun terhalang mewarisi. Pemerintah menjadikan wasiat wajibah untuk anak angkat dalam KHI sebagai solusi untuk menjawab permasalahan ini.
\end{abstract}

Kata Kunci: Wasiat Wajibah, Anak Angkat, Siyāsah al-Syar'iyah

\section{Pendahuluan}

Dalam Kompilasi Hukum Islam terdapat satu pasal yang menjadi polemik di kalangan ahli hukum di Indonesia, yaitu Pasal 209 yang mengatur tentang wasiat wajibah kepada anak angkat. Dalam berbagai literatur fikih klasik maupun perundang-undangan di berbagai negara muslim, wasiat wajibah diperuntukkan bagi kerabat (ahli waris) yang terhalang mewarisi. Sedangkan dalam Kompilasi Hukum Islam wasiat wajibah justeru diperuntukkan kepada anak angkat. Perubahan sasaran 
wasiat wajibah dari kerabat kepada anak angkat dalam Kompilasi Hukum Islam tidak diketahui secara pasti landasan hukumnya, padahal setiap aturan hukum harus mempunyai landasan yuridis yang jelas supaya ketentuan tersebut dapat diterima dan berlaku efektif dalam masyarakat. ${ }^{1}$

Landasan hukum Islam terdiri atas tiga unsur, yaitu adanya naș (mașadir alahkām), metode istinbath (qaidah al-ahkām) dan tujuan atau implikasi hukum (maqașid al-ahkam). Naș adalah asal muasal atau hakikat dari hukum Islam. Pencarian naș merupakan proses hukum yang pertama sebelum proses-proses berikutnya yaitu metode istinbath dan tujuan (implikasi) dari hukum. Metode istinbath hukum adalah the way atau cara untuk memperoleh hukum. Metode istinbath hukum Islam tidak bergerak dalam ruang yang bebas (the free space) sebagaimana hukum sekuler, namun metode istinbath atau epistemologi hukum Islam menjelaskan metode yang benar untuk menggapai hukum dengan landasan materil (naș) dan nilai spiritual sekaligus.

Sedangkan tujuan atau implikasi hukum adalah kajian yang berkenaan tentang bagaimana suatu hukum mampu menyelesaikan permasalahan yang hadir di tengah-tengah masyarakat. Nilai kegunaan hukum akan benar-benar kentara ketika memasuki wilayah aksiologi. Sehingga wajar jika kebanyakan hukum harus direkonstruksi atau ditinggalkan begitu saja karena tidak memberikan kontribusi bagi kehidupan. Hukum mengalami proses seleksi yang memang sangat bergantung kepada keadaan, semampunya setiap produk hukum harus menjadi solusi bagi permasalahan masyarakat. $^{2}$

Sebagai produk hukum Islam, wasiat wajibah untuk anak angkat harus diuji secara metodelogis menggunakan kaidah usul fikih dengan tujuan mengukur keabsahan ketentuan tersebut. Kaidah usul fikih merupakan perangkat untuk menganalisis dan menyimpulkan hukum yang sesuai dengan maqașid al-syari'ah. Berangkat dari latar belakang tersebut, maka tulisan ini bertujuan menganalisis dan mengukur keabsahan ketentuan wasiat wajibah kepada anak angkat dengan pendekatan siyāsah al-syar'iyyah.

\section{Definisi Siyāsah al-Syar'iyyah}

Siyāsah al-syar'iyyah merupakan metode pembentukan hukum yang dilakukan oleh pemerintah terhadap permasalahan yang belum ada ketentuan hukumnya atau tidak diatur secara eksplisit oleh naș melalui pertimbangan kemaslahatan bagi masyarakat. Disatu sisi siyāsah al-syar'iyyah menyerupai mașlahah al-mursalah dari sisi pembentukan hukum terhadap permasalahan yang belum ada ketentuan hukum berdasarkan pertimbangan kemaslahatan, di sisi yang lain keduanya berbeda,

\footnotetext{
${ }^{1}$ Beni Ahmad Saebeni, Filsafat Hukum Islam, (Bandung: Pustaka Setia, 2007), hlm. 61.

${ }^{2}$ M. Amien, Epistemologi Islam: Pengantar Filsafat Pengetahuan Islam, (Jakarta: UI Press, 1983), hlm. 3.
} 
mașlahah al-mursalah dilaksanakan oleh individu untuk membentuk hukum, sedangkan siyāsah al-syar'iyyah dilaksanakan oleh pemerintah.

Abdul Wahab Khalaf mendefinisikan siyāsah al-syar'iyyah sebagai tindakan atau kebijakan pemerintah berdasarkan pertimbangan kemaslahatan bagi permasalahan yang tidak diatur secara spesifik oleh naș. ${ }^{3}$ Dalam hal ini pemerintah menempuh sebuah kebijakan atau membuat undang-undang yang dipandang mengandung kemaslahatan bagi kelangsungan hidup masyarakat, namun kebijakan dan aturan tersebut tidak keluar dari koridor hukum syara'.

Pemerintah mempunyai wewenang mengambil kebijakan atas dasar kemaslahatan masyarakat untuk menerbitkan suatu peraturan, atau menunda bahkan menghapus sebuah peraturan yang dianggap tidak tepat untuk diberlakukan. Pemerintah dengan kekuasaan yang dimilikinya mempunyai hak untuk melakukan hal itu sepanjang dapat memberikan manfaat bagi masyarakat. Khalifah Usman bin Affan pernah mengatakan: "Allah memberikan wewenang kepada sulthan untuk menanggani sesuatu yang tidak ditanggani langsung oleh Al-Qur ān". ${ }^{4}$ Ungkapan ini menunjukkan adanya relasi kekuasaan dengan pembentukan hukum, di mana pemerintah dapat mengambil kebijakan untuk memberlakukan sebuah aturan atau tidak memberlakukannya atas dasar pertimbangan mewujudkan manfaat dan menolak mudharat.

Pemerintah dalam segala bentuk upayanya dalam menjalankan roda pemerintahan haruslah berorientasi kepada kemaslahatan rakyat, dalam hal ini pemerintah perlu membuat sistem dan aturan untuk mengatur kehidupan masyarakat sesuai dengan prinsip syari'at. Pemerintah tidak boleh berdiam diri membiarkan terjadinya kekosongan hukum dalam masyarakat yang mengakibatkan kegamangan dan ketidakadilan, pemerintah harus mengambil langkah-langkah konkrit mengatasinya dengan membuat aturan yang dibutuhkan.

Pemerintahan adalah suatu yang dharuri (penting) bagi masyarakat, di mana mereka tidak mungkin hidup secara layak tanpa dinaungi oleh suatu pemerintahan atau kekuatan politik yang mengatur dan melindungi. Tujuan pemerintahan adalah untuk menjamin kestabilan, keamanan dan ketentraman hidup masyarakat, sulit dibayangkan jika pemerintahan tidak ada, masyarakat akan mengalami kesulitan yang luar biasa yang mengancam eksistensi mereka. Kehidupan masyarakat tanpa dipayungi sistem pemerintahan akan berlaku hukum rimba di mana yang kuat akan menindas yang lemah, kestabilan dan kenyamanan hidup sulit terwujud dan seterusnya.

${ }^{3}$ Abdul Wahab Khallaf, Siyasah Syar iyyah Aw Nizam al-Daulah Islamiyah Fi Syuun al-Dusturiyah wa al-Kharijiah wa al-Maliyah; (Kaherah: Dar al-Ansar, 1982), hlm. 18.

"Jamal al-Din al-'Athiyyah, Nahwa Taf'il Maqașid al-Syari'ah, (Damaskus: Dar al-Fikr, 2001), hlm. 50. 
Untuk itu dilembagakanlah siyāsah al-syar'iyyah yang merupakan instrumen hukum Islam yang mengatur tatanan kehidupan masyarakat di bawah sistem pemerintahan yang islami untuk mewujudkan manfaat dan menolak kemudharatan bagi masyarakat. Ibnu Khaldun mengemukakan bahwa siyāsah al-syar'iyyah adalah suatu mekanisme untuk mengurus negara, melaksanakan hukum, dan merancang aturan perundang-undangan. Dalam hal ini pemerintah dapat menempuh dua langkah: (1) siyāsah al-diniyyah,yaitu menggunakan ketentuan atau prinsip yang terdapat dalam naș (al-Qur'ān-hadis) yang wajib dipatuhi oleh setiap orang beriman. (2) siyāsah al-'akliyah, yaitu menggunakan konsep yang disandarkan kepada akal dalam bentuk tindakan dan kebijakan yang bertujuan untuk kemaslahatan masyarakat seluruhnya. ${ }^{5}$

Dengan demikian pemerintah dalam mengurus rakyat pertama sekali harus merujuk kepada ketentuan yang terdapat dalam naș dengan cara menggali apa saja nilai dan prinsip yang diajarkan naș dalam menjalankan roda pemerintahan dan mengurus kepentingan rakyat. Di samping itu pemerintah juga dapat menggunakan rasio dalam menentukan kebijakan pada permasalahan yang tidak diatur secara langsung oleh naș, ataupun merasionalkan kandungan naș dengan kebijakankebijakan yang konkrit.

Ibn Abidin mengemukakan bahwa siyāsah al-syar'iyyah adalah suatu mekanisme atau pengaturan yang bertujuan untuk memperbaiki keadaan masyarakat dengan cara membimbing dan mengarahkan mereka kepada keselamatan dunia dan akhirat. ${ }^{6}$ Definisi ini menunjukkan bahwa pemberlakuan hukum Islam di pemerintahan merupakan suatu yang primer dalam arti sebagai instrumen utama yang digunakan pemerintah untuk mengendalikan kehidupan masyarakat supaya mendapat keselamatan dunia dan akhirat, karena hanya hukum Islam yang mungkin mewujudkan tujuan tersebut.

Hal senada juga dikemukakan oleh Imam al-Haramain bahwasanya tugas pemerintah mencakup pemenuhan segala kepentingan masyarakat baik yang umum maupun yang khusus menyangkut urusan agama dan dunia. Pemerintah tidak hanya memikirkan kebahagiaan hidup di dunia semata, akan tetapi juga kebahagiaan hidup di akhirat kelak. Untuk itu pemerintah di samping mengupayakan kesejahteraan dan keamanan yang berorientasi duniawi juga harus menegakkan dakwah dan memerintahkan pengamalan agama yang berorientasi ukhrawi kepada masyarakat.

Pengaturan pemerintahan berdasarkan siyāsah al-syar'iyyah akan lebih terjamin kesejahteraan, kestabilan dan keharmonisan tatanan sosial masyarakat, sesuai dengan maksud syari'at (rahmatan lil 'alamin). Sebaliknya pemerintah yang

${ }^{5} \mathrm{Ibnu}$ Khaldun, Muqaddimah, (Beirut: t.p, tt), hlm. 302-311.

${ }^{6}$ Ibn Abidin, Hasyiah Radd al-Muhtar 'ala al Durr al Mukhtar, Juz 4, (Beirut: Dar al-Fikr, 1992), hlm. 15. 
mengabaikan syari'at berpotensi muncul ketidakstabilan dan ketidakadilan. Masyarakat akan hidup di bawah bayangan tirani penguasa sehingga hubungan pemerintah dan masyarakat tidak harmonis dan langgeng. Pemerintahan yang tidak berlandaskan syari'at Islam cenderung mementingkan penguasa dan mengabaikan masyarakat, hal ini dapat menjadi bom waktu yang dapat meledak kapan saja, antara masyarakat dan penguasa akan terjadi bentrok dan pertumpahan darah.

Yusuf Al-Qaradhawi mengemukakan bahwa siyāsah al-syar'iyyah merupakan suatu sistem politik yang menjadikan syari'at Islam sebagai acuan, mengaplikasikannya di muka bumi dan di tengah-tengah masyarakat, untuk mencapai tujuan hidup masyarakat sesuai syari'at. ${ }^{7}$ Yusuf al-Qaradhawi menolak dengan keras penggunaan sistem politik yang bukan Islam untuk pengaturan pemerintahan yang ada diberbagai negara muslim. Ia menolak sistem politik sekuler yang memisahkan antara urusan negara dan agama, sehingga dapat menghalalkan segala macam cara untuk mencapai tujuan politik sekalipun mengabaikan nilai-nilai moral.

Dalam sistem politik yang bukan berdasarkan syariat Islam, segala upaya seperti adu domba, mengancam, menyingkirkan bahkan pembunuhan terhadap lawan-lawan politik merupakan norma yang biasa untuk dapat mencapai tujuan, sedangkan menurut siyāsah al-syar'iyyah hal-hal semacam itu tidak dibenarkan karena dianggap merugikan pihak lain dan membuka jalan bagi munculnya pemerintahan tirani yang mengancam kestabilan dan keharmonisan hidup masyarakat.

Abdurrahman Taj mengemukakan bahwa siyāsah al-syar'iyyah merupakan hukum atau peraturan yang dibuat pemerintah untuk mengatur pemerintahan dan rakyat yang sesuai dengan prinsip syari'at, qaidah kulliyah, dan dapat diterima oleh masyarakat, sekalipun hukum dan peraturan tersebut tidak dijelaskan secara langsung oleh naș (al-Qur'ān-Sunnah). ${ }^{8}$ Siyasah al-syarī'ah merupakan kebijakan pemerintah berupa ijtihadnya untuk membentuk hukum atau aturan yang dirasa penting dan maslahat bagi tata kelola pemerintahan dan rakyat. Pemerintah diberikan wewenang membuat kebijakan terhadap permasalahan yang tidak diatur secara langsung oleh naș, kebijakan tersebut dapat diterima sepanjang tidak bertentangan dengan nas dan prinsip-prinsip umum hukum Islam.

Dari berbagai perspektif yang telah dikemukakan di atas, dapat dipahami bahwa siyāsah al-syar'iyyah di satu sisi merupakan sistem politik atau tata cara pengelolaan pemerintahan yang berlandaskan kepada syariat Islam untuk mewujudkan kesejahteraan, kestabilan dan keharmonisan hidup masyarakat sesuai dengan maksud dan tujuan syara'. Maka dalam segala lini pemerintahan baik

7Yusuf al-Qaradhawi, Siyasah al-Syariah, (Beirut: Dar al Syuruq, tt), hlm. 230.

${ }^{8} \mathrm{Abd}$ al-Rahman al-Taj, Al-Siyasah al-Syari'ah wa Figh al-Islamy, (Kaherah: al-Azhar, $\left.1415 \mathrm{H}\right)$, hlm. 12. 
eksekutif, legislatif maupun yudikatif harus dilaksanakan sesuai dengan prinsip Islam.

\section{Fungsi dan Tujuan Siyāsah al-Syar'iyyah}

Siyāsah al-syar'iyyah merupakan upaya pemerintah untuk membuat aturan hukum atau undang-undang bagi permasalahan yang tidak diatur secara jelas oleh naș, menggunakan metode istinbath hukum yang berlaku supaya terwujudnya kemaslahatan bagi kehidupan rakyat. Maka siyāsah al-syar'iyyah dapat dipahami sebagai sistem politik Islam untuk mengatur pemerintahan di satu sisi dan kebijakan pemerintah untuk membuat aturan perundang-undangan di sisi yang lain.

Kedudukan siyāsah al-syar'iyyah dalam pemerintahan tidak bisa diabaikan, karena merupakan salah satu instrumen utama dalam penegakan hukum untuk mewujudkan maqasid al-syarī'ah. Melalui siyāsah al-syar'iyyah hukum Islam diupayakan atau hanya mungkin diaplikasikan dalam masyarakat, karena hukum tanpa adanya dukungan politik tidak mungkin dijalankan, kekuasaan sangat menentukan terutama perkara yang berkaitan dengan pelaksanaan undang-undang, tatanan kehidupan dan segala aspeknya. Di sisi yang lain kekuasaan tanpa berlandaskan kepada aturan hukum juga tidak akan efektif dan akan menjurus kepada kedurjanaan penguasa, yang semena-mena dalam menjalankan hukum sehingga merugikan masyarakat.

Pemerintahan merupakan sarana bagi pelaksanaan hukum dan mencapai tujuan syari'at, sebagaimana dipahami dari kandungan QS. Al-Anbiya (21) : 107, yaitu: "Dan Tiadalah Kami mengutus kamu, melainkan untuk (menjadi) rahmat bagi semesta alam". Dan juga dipahami dari kandungan QS.Al-Hajj (22) : 41: “(yaitu) orang-orang yang jika Kami teguhkan kedudukan mereka di muka bumi niscaya mereka mendirikan sembahyang, menunaikan zakat, menyuruh berbuat ma'ruf dan mencegah dari perbuatan yang mungkar; dan kepada Allah-lah kembali segala urusan. (QS. Al-Hajj (22) : 41)

Kedua ayat di atas menjelaskan tentang tujuan pemerintahan atau pemimpin, Rasulullah Saw diutus oleh Allah Swt sebagai pemimpin untuk membimbing umat manusia ke jalan yang lurus demi mencapai keridhaan-Nya dan kebahagiaan hidup dunia dan akhirat. Demikian pula diutusnya orang-orang saleh lainnya juga untuk menjalankan amanah Allah berupa mendirikan salat, menunaikan zakat dan mengajak manusia mengamalkan yang ma'ruf dan meninggalkan yang mungkar. Pemerintah bertugas memberikan tauladan yang baik dan menjalankan hukum dalam masyarakat, serta bertanggungjawab kepada terealisasinya maqașid alsyar'iyyah secara nyata dimuka bumi dalam kehidupan masyarakat.

Dalam mengemban amanah tersebut pemerintah harus menggunakan panduan yang benar berupa siyāsah al-syar'iyyah, yang berarti tata cara mengurus pemerintahan dan urusan umat berdasarkan prinsip Islam, dan secara khusus siyāsah 
al-syar'iyyah juga berarti mengurus negara dan agama dengan membuat hukum bagi perkara yang tidak mempunyai naș yang jelas, atau melakukan suatu perubahan hukum yang bertumpu kepada prinsip umum naș untuk mewujudkan kemaslahatan umat.

Melalui siyāsah al-syar'iyyah pemerintah mengupayakan untuk mencapai tujuan syara' dalam bidang pengelolaan negara dan persoalan umat secara optimal. Pemerintah melaksanakan aturan yang telah digariskan dalam hukum Islam dalam mengelola negara, atau melakukan ijtihad untuk mengambil suatu kebijakan bagi permasalahan yang belum mempunyai ketentuan hukum yang jelas dalam naș. Di samping itu pemerintah juga berhak melakukan perubahan hukum jika keadaan menghendakinya.

Fungsi atau kegunaan siyāsah al-syar'iyyah dalam pembinaan dan penegakan hukum setidaknya terdiri atas dua bentuk, yaitu:

1. Menentukan hukum bagi perkara-perkara baru yang tidak mempunyai dalil khusus dalam al-Qur'ān, Sunnah, Ijma', Qiyas, dan pendapat para ulama. Untuk itu pemerintah dapat menempuh upaya hukum melalui kaidah-kaidah ushūl figh seperti mașlahah al-mursalah, istihsan, sad al-zara'i, dan 'urf.

2. Menentukan kemaslahatan yang sifatnya kondisional atau temporal pada kasus-kasus tertentu yang mungkin berubah mengikuti perubahan waktu dan tempat. Pada kasus-kasus tersebut pemerintah dapat mengambil kebijakan untuk melakukan penyimpangan dari ketentuan hukum yang ada jika dinilai perlu perubahan hukum dengan yang baru. ${ }^{9}$

Pemerintah dengan kekuasaan yang dimilikinya dapat melakukan kedua bentuk upaya di atas sepanjang mampu memastikan bahwa pembentukan hukum atau perubahannya merupakan kebutuhan masyarakat yang perlu dilakukan untuk menghindari kerusakan dan kebinasaan, selanjutnya kebijakan yang diambil pemerintah tersebut juga tidak bertentangan dengan maksud naș dan prinsip-prinsip umum syari'at Islam.

Kebijakan pemerintah atau siyāsah al-syar'iyyah tidak selamanya merupakan kebenaran dan harus diterima. Menurut Ibnu Farhun, siyāsah terbagi kepada dua macam yaitu: (1) siyāsah al-'adilah, yang membela suatu kebenaran dari upaya kezaliman, menolak pelbagai bentuk kejahatan, menghalangi pembuat kerusakan dan yang menghantarkan kepada tercapainya tujuan-tujuan syara'. (2) siyāsah al-dzalimah, yang membela kesalahan, kezaliman, kejahatan, kerusakan dan menghambat tercapainya tujuan syara'. ${ }^{10}$ Dalam konteks pengambilan kebijakan, pemerintah harus

${ }^{9}$ Abdul Ahmad al-Atwah, Al-Madkhal ila al-Siyasah al-Syari'ah, (Riyadh: Jamiah al-Imam Muhammad bin Saud al-Islamiyyah, 1994), hlm. 13-14.

${ }^{10} \mathrm{Ibnu}$ Farhun, Tabshirah al-Hukam fi Ushūl al-'Aqdiyyah wa Manahij al-Ahkām, (Beirut: t.p, tt), hlm. 35. 
mengacu kepada siyāsah al-'adilah, yaitu siyāsah yang berpihak kepada kebenaran, keselamatan dan kesejahteraan masyarakat serta tidak bertentangan dengan prinsip hukum Islam.

Dalam masyarakat senantiasa muncul permasalahan yang membutuhkan perhatian pemerintah, sebahagiannya merupakan permasalahan yang tidak diatur secara jelas oleh naș, seperti permasalahan wasiat wajibah kepada anak angkat. Secara realitas aturan ini sangat dibutuhkan oleh masyarakat untuk mewujudkan kepastian hukum dan memenuhi rasa keadilan terhadap anak angkat. Untuk itu pemerintah harus memperhatikan permasalahan ini dengan membentuk suatu ketentuan hukum yang dianggap tepat dan solutif.

\section{Tinjauan Siyāsah al-Syar'iyyah Terhadap Wasiat wajibah Untuk Anak Angkat}

Wasiat wajibah kepada anak angkat merupakan aturan hukum yang berjalan berdasarkan kebijakan pemerintah untuk menjawab persoalan di antara ahli waris atau orang yang dekat dengan pewaris namun terhalang mewarisi, padahal seharusnya mereka berhak memperolehnya. Untuk itu pemerintah menjadikan wasiat wajibah sebagai solusi untuk menjawab permasalahan ini.

Di Indonesia, wasiat wajibah kepada anak angkat sebenarnya telah diatur melalui Inpres Nomor 1 Tahun 1991 tentang Kompilasi Hukum Islam. Pada Pasal 209 ayat 1 dan 2 disebutkan:

(1) Harta peninggalan anak angkat dibagi berdasarkan Pasal 176 sampai dengan

Pasal 193 tersebut di atas, sedangkan terhadap orang tua angkat yang tidak menerima wasiat diberi wasiat wajibah sebanyak-banyaknya $1 / 3$ dari harta wasiat anak angkatnya.

(2) Terhadap anak angkat yang tidak menerima wasiat diberi wasiat wajibah sebanyak-banyaknya $1 / 3$ dari harta warisan orang tua angkatnya. ${ }^{11}$

Dari bunyi frasa hukum di atas dapat dipahami bahwa anak angkat dan orang tua angkat masing-masing mempunyai hak untuk menerima wasiat wajibah sebanyakbanyaknya sepertiga harta, dengan syarat ketika hidup mereka tidak pernah menerima harta dalam bentuk hibah atau wasiat. Sepertiga harta merupakan batasan maksimal wasiat wajibah yang diterima oleh anak dan orang tua angkat, ini menunjukkan bahwa tidak ada suatu kemestian merealisasikan wasiat wajibah sejumlah sepertiga, namun boleh jadi lebih sedikit tergantung pertimbangan hakim ketika melihat kondisi ahli waris dan harta yang ditinggalkan.

Ketentuan wasiat wajibah kepada anak angkat yang demikian jika dikaitkan dengan hasil kajian metode 'urf dan istiṣlāhiah di atas telah sejalan dengan kesadaran hukum masyarakat, dan mempunyai maslahat dalam bentuk pemenuhan keadilan bagi anak angkat. Ketentuan wasiat wajibah dalam Kompilasi Hukum Islam telah

\footnotetext{
${ }^{11}$ Departemen Agama RI, Tanya Jawab Kompilasi Hukum Islam, hlm. 143.
} 
mengakomodir hak harta anak angkat tanpa mengabaikan hak-hak ahli waris, sebagaimana dipahami dari frasa hukum "wasiat wajibah sebanyak-banyaknya sepertiga harta", di mana kepada anak angkat tetap diberikan wasiat wajibah dalam batas sepertiga harta, yaitu disesuaikan dengan jumlah harta dan kondisi ahli waris. Ketentuan yang demikian nampak proporsional dan akomodatif bagi kepentingan berbagai pihak baik kerabat maupun anak angkat.

Kompilasi Hukum Islam merupakan salah satu bentuk siyasah al-syari'ah yang dilakukan pemerintah untuk mengaktualisasi hukum Islam yang sesuai dengan kebutuhan hukum dan kepribadian masyarakat Indonesia lewat pen-tarjih-an dan kompromisasi pendapat ulama dari berbagai mazhab serta memperhatikan 'urf masyarakat. KHI mengarah kepada unifikasi mazhab dalam hukum Islam, dan jika dikaitkan dengan sistem hukum Indonesia, ini merupakan bentuk terdekat dengan kodifikasi hukum yang menjadi arah pembangunan hukum Nasional. ${ }^{12}$

Tujuan penyusunan Kompilasi Hukum Islam adalah untuk mempositifkan hukum Islam di Indonesia, agar dijadikan pedoman oleh para hakim dalam melaksanakan tugasnya sehingga terjamin adanya kesatuan dan kepastian hukum. Karena untuk dapat berlakunya hukum Islam di Indonesia, harus ada antara lain hukum yang jelas dan dapat dilaksanakan oleh aparat penegak hukum dan masyarakat. Dengan lahirnya KHI, semua hakim di lingkungan Pengadilan Agama diarahkan kepada persepsi penegakan hukum yang sama. ${ }^{13}$

Namun kedudukan KHI berdasarkan Inpres Nomor 1 Tahun 1991 menurut sebahagian pakar dianggap lemah, KHI disebutkan sebagai dokumen yustisia yang berguna sebagai pedoman bagi hakim di lingkungan Badan Peradilan Agama sebagai hukum terapan dalam menyelesaikan perkara-perkara yang diajukan kepadanya. Abdurrahman mengemukakan bahwa penyebutan pedoman yustisia di sini tidak ditemukan penjelasan apa sebenarnya yang dimaksud pedoman, akan tetapi dari susunan kata/kalimat "dapat digunakan sebagai pedoman" dapat menumbuhkan kesan bahwa KHI tidak mengikat, artinya para pihak dan instansi dapat memakainya dan dapat pula tidak memakainya. Hal ini tentu saja tidak sesuai dengan harapan yang dikemukan pada latar belakang penyusunan dan penetapan $\mathrm{KHI}$ itu sendiri supaya menjadi hukum positif. Untuk itu pengertian sebagai pedoman harus bermakna sebagai tuntunan atau petunjuk yang harus dipakai baik oleh Pengadilan Agama maupun warga masyarakat dalam menyelesaikan sengketa di antara mereka dalam bidang hukum perkawinan, kewarisan dan perwakafan. ${ }^{14}$

\footnotetext{
${ }^{12}$ Lihat Buku Kompilasi Hukum Islam di Indonesia, (Jakarta: Depag RI, tt), hlm. 126.

${ }^{13}$ M. Yahya Harahap, Informasi Materi KHI, Mempositifkan Abstraksi Hukum Islam, dalam Mimbar Hukum: Aktulalisasi Hukum Islam, No. 5 (Jakarta: Al-Hikmah: 1992), hlm 25.

${ }^{14}$ Abdurrahman, Kompilasi Hukum Islam di Indonesia, (Jakarta: Akademika Pressindo, 1993), Cet, 3, hlm. 55.
} 
Moch Kosnoe dalam Habiburrahman mengemukakan bahwa KHI meskipun berdasarkan Instruksi Presiden kepada Menteri Agama, kedudukan KHI menurut sistem hukum Nasional tetap sebagai suatu karya dari perorangan dan bukan merupakan peraturan resmi yang keluar dari instansi pemerintah, lebih-lebih lagi bukanlah suatu undang-undang, dengan kata lain KHI tidak mempunyai kedudukan sebagai aturan tertulis di dalam sistem hukum Nasional. ${ }^{15}$

Natabaya juga menganggap kedudukan hukum KHI lemah, ia mengemukakan bahwa Instruksi Menteri bukanlah jenis peraturan perundangundangan karena instruksi hanya mengikat intern suatu organisasi (baik pemerintah/negara maupun non pemerintah). Seandainya pun mengikat keluar (external) sebatas pada orang atau instansi yang diberikan instruksi tersebut. Dengan demikian, maka Instruksi Menteri dan Instruksi Presiden tidak termasuk dalam jenis peraturan perundang-undangan. ${ }^{16}$

Undang-Undang Nomor 12 Tahun 2011 tentang Pembentukan Peraturan Perundang-undangan telah mengatur hirarki peraturan perundang-undangan, di Indonesia, yaitu:

1. Undang-Undang Dasar Negara Republik Indonesia Tahun 1945;

2. Ketetapan MPR;

3. Undang-Undang/Peraturan Pemerintah Pengganti Undang-Undang;

4. Peraturan Presiden;

5. Peraturan Daerah Provinsi;

6. Peraturan Daerah Kabupaten/Kota.

Berdasarkan hirarki peraturan perundang-undangan di atas terlihat bahwa Instruksi Presiden tidak termasuk salah satu di antaranya, sehingga dapat dipahami bahwa kedudukan Inpres bukanlah peraturan perundang-undangan. Kedudukan hukum Inpres tidak mempunyai daya mengikat ekternal, akan tetapi terkhusus bagi lembaga pemerintah atau non pemerintah yang ditujukan saja. Realitas yang demikian menunjukkan bahwa kedudukan KHI sebagai hukum positif masih lemah, dan belum mampu menjamin kepastian hukum melalui rujukan hukum yang satu. Padahal tujuan dari KHI itu sendiri sebagaimana telah disebutkan adalah untuk menyamakan persepsi para hakim Pengadilan Agama dalam memutuskan hukum bagi masyarakat, di mana sebelumnya telah terjadi disparitas (perbedaan) antara satu hakim dan lainnya dalam memutuskan suatu perkara yang sama akibat berbeda rujukan yang digunakan.

${ }^{15}$ Habiburrahman, Rekonstruksi Hukum Kewarisan Islam di Indonesia, (Jakarta: Prenada Media Group, 2011), Cet. 1, hlm 54.

${ }^{16}$ H.A.S. Natabaya, Sistem Peraturan Perundang-Undangan Indonesia, (Jakarta: Mahkamah Konstitusi, 2006), hlm 117-118. 
Kedudukan KHI diharapkan dapat memberikan kepastian hukum materil bagi umat Islam Indonesia, karena sifatnya yang tertulis sehingga dapat dijadikan rujukan hukum Islam dalam menyelesaikan sengketa dalam masalah hukum perkawinan, kewarisan, dan perwakafan. Apalagi mengingat KHI merupakan konsensus para yuris Islam di Indonesia yang telah mentransendenkan hukum yang hidup dalam masyarakat ke dalam bentuk hukum tertulis. Untuk itu kedudukan KHI perlu diperkuat tidak hanya sebatas Inpres, akan tetapi harus ditingkatkan menjadi peraturan perundang-undangan.

Secara realitas umat Islam merupakan jumlah mayoritas di Indonesia, dan sangat mengharapkan hukum Islam dapat menjadi hukum positif. Hal ini didasarkan pada cara berfikir, pandangan hidup dan karakter suatu bangsa tercermin dalam kebudayaan dan hukumnya. ${ }^{17}$ Kenyataan ini juga sesuai dengan sejarah panjang agama Islam di Indonesia hingga interaksinya dengan hukum barat yang dibawa oleh kolonial Belanda yang mengakui akan berlakunya hukum Islam dalam lapangan hukum keperdataan tertentu. Antara lain dibidang kewarisan yang dianggap sebagai salah satu bidang hukum di luar bidang-bidang yang bersifat netral seperti hukum perseroaan, hukum kontrak (perikatan) dan hukum lalu lintas (darat, air dan udara). Bidang waris termasuk bidang hukum yang mengandung terlalu banyak halangan, adanya komplikasi-komplikasi kultural, keagamaan dan sosiologi, sehingga menyulitkan diterapkan hukum selain Islam. ${ }^{18}$

Hukum waris atau faraid merupakan salah satu hukum Islam yang hingga sekarang masih berlaku dan diberlakukan di Indonesia khususnya bagi umat Islam. Para yuris Islam telah sepakat bahwa hukum waris Islam merupakan hukum yang muncul dari dalil-dalil yang pasti ( $q a t h{ }^{\prime} i$ ) berupa teks al-Qur'an dan Hadīs. Hukum waris Islam dianggap suatu kewajiban yang harus dilaksanakan oleh setiap muslim, yang dianggap sebagai compulsory law, yaitu hukum yang berlaku secara mutlak dan baku. ${ }^{19}$

Namun ada juga bidang-bidang tertentu dalam hukum waris yang tidak prinsipil bisa saja ditafsirkan dan direkonstruksi sesuai dengan kondisi-kondisi yang memungkinkan untuk dipertimbangkan. Secara realistis ada beberapa masalah dalam hukum waris yang menjadi polemik di antara para yuris Islam karena naș tentang masalah tersebut tidak tegas (dilalah dzanni), di mana petunjuk untuk memahami naș tersebut memungkinkan perbedaan pendapat di kalangan para ulama. Misalnya QS. Al-Nisa menyangkut mawali, sebahagian ulama memahaminya sebagai ahli waris

\footnotetext{
${ }^{17 R}$. Subekti, Perbandingan Hukum Perdata, (Jakarta: Pradnya Paramita, 1993), Cet. 12, hlm. 3.

${ }^{18}$ Mochtar Kusumaatmadja, Hukum Masyarakat dan Pembinaan Hukum Nasional, (Bandung: Bina Cipta, 1976), hlm. 12-14.

${ }^{19}$ Aminullah, Sekitar Formulasi Hukum Kewarisan dalam Semangat Reaktualisasi Ajaran Islam, dalam Munawir Sjadzali, dkk., Polemik Reaktualisasi Ajaran Islam, (Jakarta: Panjimas, 1988), hlm. 164.
} 
pengganti, sehagian ulama yang lain tidak memahaminya demikian. ${ }^{20}$ Demikian pula permasalahan wasiat wajibah, sebahagian ulama memandang hukumnya sunat, kewajiban wasiat hanya berlaku pada awal Islam, kemudian dibatalkan oleh ayatayat waris. Sedangkan ulama yang lain menganggap bahwa kewajiban wasiat masih tetap berlaku kepada kerabat yang tidak mewarisi.

Dari uraian di atas dapat dipahami bahwa kedudukan KHI perlu diperkuat oleh pemerintah menjadi hukum positif dalam bentuk aturan perundang-undangan yang mempunyai kekuatan hukum mengikat. Hal ini pantas dilakukan untuk menyahuti tuntutan dan desakan umat Islam yang secara terus menerus berlangsung sampai sekarang supaya hukum Islam menjadi hukum positif. Masyarakat Islam merasakan bahwa hukum Islam merupakan norma yang perlu ditegakkan, setidaknya tidak dirasakan sebagai norma hukum yang dipaksakan dari luar diri mereka. Secara sosiologis menunjukkan bahwa hukum Islam hidup dan inheren dalam kehidupan umat Islam di Indonesia, oleh sebab itu hukum Islam sangat layak dijadikan hukum positif dalam bentuk perundang-undangan.

Alasan sosiologis di atas juga sesuai dengan amanat Undang-undang Nomor 48 Tahun 2009 tentang Pokok-Pokok Kekuasaan Kehakiman Pasal 5 ayat 1 yang berbunyi: "Hakim dan hakim konstitusi wajib menggali, mengikuti, dan memahami nilainilai hukum dan rasa keadilan yang hidup dalam masyarakat. Penjelasannya menyatakan ketentuan ini dimaksudkan agar putusan hakim sesuai dengan hukum dan rasa keadilan masyarakat". Berdasarkan ketentuan pasal tersebut dapat dipahami bahwa hukum Islam, khususnya hukum waris merupakan hukum yang hidup dalam masyarakat di Indonesia pantas dijadikan hukum positif dalam bentuk peraturan perundangundangan.

Proses tranformasi hukum waris Islam ke dalam bentuk perundang-undangan (takhrij al-ahkam fi al-naș al-qanun) terjadi melalui proses interaksi antar elit politik Islam, yaitu para ulama, tokoh ormas, pejabat agama dan cendikiawan muslim dengan elit kekuasaan (the rulling elite), yaitu kalangan politisi dan pejabat negara. Dengan interaksi yang efektif antara elit tersebut peraturan perundang-undangan dapat diwujudkan. Sebagai contoh, diundangkan nya Undang-Undang Perkawinan Nomor 1 Tahun 1974, di mana peranan elit Islam cukup dominan di dalam melakukan pendekatan dengan elit ditingkat legislatif, sehingga RUU Perkawinan Nomor 1 Tahun 1974 dapat dikodifikasikan.

Adapun prosedur pengambilan keputusan politik ditingkat legislatif dan eksekutif dalam hal legislasi hukum Islam (legal drafting) hendaknya mengacu kepada politik hukum yang dianut oleh badan kekuasaan negara secara kolektif. Suatu undang-undang dapat ditetapkan sebagai peraturan tertulis yang dikodifikasikan

${ }^{20}$ Sukris Sarmadi, Dekonstruksi Hukum Progresif Ahli Waris Pengganti dalam Kompilasi Hukum Islam, (Yokyakarta: Aswaja Pressindo, 2012), Cet. 2, hlm. 10. 
apabila telah melalui proses politik pada badan kekuasaan negara yaitu legislatif dan eksekutif, serta memenuhi persyaratan dan rancangan perundang-undangan yang layak.

Pendekatan konstitusional prosedur legislasi hukum Islam menurut A. Hamid S. Attamimi dalam Habiburrahman bahwa Pemerintah dan DPR memegang kekuasaan di dalam pembentukan undang-undang. Disebutkan pada Pasal 5 ayat 1 UUD 1945 bahwa "Presiden memegang kekuasaan membentuk undang-undang dengan persetujuan Dewan Perwakilan Rakyat". Adapun dalam penjelasannya mengenai pasal tersebut dinyatakan bahwa "kecuali executif power, presiden bersama-sama dengan Dewan Perwakilan Rakyat menjalankan legislatif power dalam negara". ${ }^{21}$

Kekhususan undang-undang dibandingkan peraturan lainnya, bahwa undang-undang dibentuk dan ditetapkan oleh presiden dengan persetujuan DPR. Muatan materi undang-undang akan menjadi pedoman bagi peraturan-peraturan lain di bawahnya. Pedoman untuk mengetahui materi yang termuat dalam undangundang dapat ditentukan melalui tiga pedoman, yaitu: pertama, dari ketentuan dalam batang tubuh UUD 1945 terdapat sekitar 18 masalah (18 pasal) tentang hak-hak asasi manusia, pembagian kekuasaan negara, dan penetapan organisasi dan alat kelengkapan negara; kedua, berdasarkan wawasan negara yang berdasarkan atas hukum (rechtstaat) yang dimulai dari kekuasaan absolut negara (polizeistaat), seterusnya pembentukan negara berdasarkan atas hukum yang sempit/liberal (rechtstaat), berdasarkan atas hukum formal (rechtstaat formal), dan negara berdasarkan atas hukum material/sosial yang modern (rechtstaat material/sosial); dan ketiga, berdasarkan wawasan pemerintahan sistem konstitusional, di mana penyelenggaraan kekuasaan negara dan hukum serta yang lainnya harus mengacu pada norma dasar (ground norm) dan undang-undang dasar, yaitu Pancasila dan UUD 1945.22

Mengacu kepada rumusan-rumusan teori hukum di atas, dapat dipahami bahwa kodifikasi hukum Islam menjadi sebuah undang-undang diharuskan mengikuti prosedur konstitusional dan sejalan dengan norma hukum serta cita hukum di Indonesia. Kodifikasi dan unifikasi hukum Islam serta penyusunan rancangan perundang-undangan yang baru diarahkan untuk menjamin kepastian hukum (law enforcement) di masyarakat.

Selain itu, pembentukan hukum harus diselenggarakan melalui proses terpadu dan demokratis berdasarkan Pancasila dan UUD 1945, serta menghasilkan produk hukum hingga tingkat peraturan pelaksanaannya (PP). Dalam pembentukan hukum perlu diindahkan ketentuan yang memenuhi nilai filosofis yang berintikan rasa keadilan dan kebenaran, nilai sosiologis yang sesuai dengan tata nilai budaya

\footnotetext{
${ }^{21}$ Habiburrahman, Rekonstruksi Hukum Kewarisan...,hlm. 58.

${ }^{22}$ Habiburrahman, Rekonstruksi Hukum Kewarisan Islam..., hlm. 59.
} 
yang berlaku di masyarakat, dan nilai yuridis yang sesuai dengan ketentuan perundang-undangan yang berlaku. ${ }^{23}$ Dengan demikian ketentuan hukum waris Islam dapat menempati kedudukan sebagai tatanan hukum yang berlaku secara formal dalam sistem hukum nasional, jika telah memenuhi ketiga persyaratan di atas.

\section{Kesimpulan}

Dari uraian di atas dapat ditarik kesimpulan bahwa wasiat wajibah kepada anak angkat merupakan aturan hukum yang berjalan berdasarkan kebijakan pemerintah untuk menjawab persoalan di antara ahli waris atau orang yang dekat dengan pewaris namun terhalang mewarisi, padahal seharusnya mereka berhak memperolehnya. Untuk itu pemerintah menjadikan wasiat wajibah sebagai solusi untuk menjawab permasalahan ini melalui Inpres Nomor 1 Tahun 1991 Tentang Kompilasi Hukum Islam.

Namun kedudukan KHI perlu diperkuat oleh pemerintah menjadi hukum positif berupa peraturan perundang-undangan yang mempunyai kekuatan hukum mengikat. Hal ini pantas dilakukan untuk menyahuti tuntutan dan desakan umat Islam yang secara terus menerus berlangsung sampai sekarang supaya hukum Islam menjadi hukum positif. Masyarakat Islam merasakan bahwa hukum Islam merupakan norma yang perlu ditegakkan, setidaknya tidak dirasakan sebagai norma hukum yang dipaksakan dari luar diri mereka. Secara sosiologis menunjukkan bahwa hukum Islam hidup dan inheren dalam kehidupan umat Islam di Indonesia, oleh sebab itu hukum Islam sangat layak dijadikan hukum positif dalam bentuk perundang-undangan.

\section{Daftar Pustaka}

Abdurrahman, Kompilasi Hukum Islam di Indonesia, (Jakarta: Akademika Pressindo, 2005), Cet, 3.

Abidin, Ibnu. Hasyiah Radd al-Muhtar 'ala al Durr al Mukhtar, Juz 4, (Beirut: Dar al-Fikr, 2000).

al-'Athiyyah, Jamal al-Din, Nahwa Taf'il Maqașid al-Syari'ah, (Damaskus: Dar al-Fikr, 2001).

al-Atwah, Abdul Ahmad, Al-Madkhal ila al-Siyasah al-Syari'ah, (Riyadh: Jamiah alImam Muhammad bin Saud al-Islamiyyah, 1994).

al-Qaradhawi, Yusuf. Siyasah al-Syariah, (Beirut: Dar al Syuruq, tt).

al-Taj, Abd al-Rahman, Al-Siyasah al-Syari'ah wa Fiqh al-Islamy, (Kaherah: al-Azhar, 1415)

${ }^{23}$ Amiruddin Syarif, Perundang-undangan; Dasar, Jenis dan Teknik Membuatnya, (Jakarta: Bumi Aksara, 1987), hlm. 91-95. 
Amien, Muhammad. Epistemologi Islam: Pengantar Filsafat Pengetahuan Islam, (Jakarta: UI Press, 1983).

Aminullah, Sekitar Formulasi Hukum Kewarisan dalam Semangat Reaktualisasi Ajaran Islam, dalam Munawir Sjadzali, dkk., Polemik Reaktualisasi Ajaran Islam, (Jakarta: Panjimas, tt).

Departemen Agama RI, Tanya Jawab Kompilasi Hukum Islam.

Farhun, Ibnu. Tabshirah al-Hukam fi Ushūl al-'Aqdiyyah wa Manahij al-Ahkām, (Beirut: t.p, $t \mathrm{t})$.

Habiburrahman, Rekonstruksi Hukum Kewarisan Islam di Indonesia, (Jakarta: Prenada Media Group, 2011), Cet.1.

Harahap, M. Yahya. Informasi Materi KHI, Mempositifkan Abstraksi Hukum Islam, dalam Mimbar Hukum: Aktulalisasi Hukum Islam, No. 5 (Jakarta: Al-Hikmah: 1992).

Khaldun, Ibnu. Muqaddimah, (Beirut: t.p, tt).

Khallaf, Abdul Wahab, Siyasah Syar iyyah Aw Nizam al-Daulah Islamiyah Fi Syuun alDusturiyah wa al-Kharijiah wa al-Maliyah; (Kaherah: Dar al-Ansar, 2000).

Kusumaatmadja, Mochtar. Hukum Masyarakat dan Pembinaan Hukum Nasional, (Bandung: Bina Cipta, tt).

Natabaya, H.A.S. Sistem Peraturan Perundang-Undangan Indonesia, (Jakarta: Mahkamah Konstitusi, 2006).

Saebeni, Beni Ahmad, Filsafat Hukum Islam, ( Bandung : Pustaka Setia, 2007).

Sarmadi, Sukris. Dekonstruksi Hukum Progresif Ahli Waris Pengganti dalam Kompilasi Hukum Islam, (Yokyakarta: Aswaja Pressindo, 2012), Cet. 2.

Subekti, R. Perbandingan Hukum Perdata, (Jakarta: Pradnya Paramita, 2005), Cet. 14.

Syarif, Amiruddin, Perundang-undangan; Dasar, Jenis dan Teknik Membuatnya, (Jakarta: Bumi Aksara, 2010). 